\title{
Differential Expression Pattern of Splice Variants of Amino Acid Transporter Genes from Rice Grown under Various Nitrogen Conditions and during Development
}

\author{
Zhongming Fang ${ }^{12^{*}}$, Qisen Zeng ${ }^{1}$, Kai Lv ${ }^{1}$, Weiting Huang ${ }^{1}$ and Mingyong Zhang ${ }^{2 *}$ \\ ${ }^{1}$ Center of Applied Biotechnology, Wuhan Institute of Bioengineering, Wuhan, China \\ ${ }^{2}$ Key Laboratory of South China Agricultural Plant Molecular Analysis and Genetic Improvement \& Guangdong Provincial \\ Key Laboratory of Applied Botany, South China Botanical Garden, Chinese Academy of Sciences, Guangzhou, China \\ *For correspondence: zmfang88@163.com; zhangmy@scbg.ac.cn; abs@academicconf.com
}

\begin{abstract}
Amino acid transporters (AATs) play indispensable roles in nutrient uptake and allocation for plants. Alternative splicing of gene's post transcription can increase diversity of protein and allow novel ways to regulate growth and development of plant. In this study, $11 O s A A T$ alternative-splicing genes with 24 kinds of predicted mRNAs were identified from 85 rice $A A T$ genes; of these, 23 alternative-splicing open reading frames were actually expressed in rice. Quantitative real time-polymerase chain reaction results showed that the predicted primary splice variant 1 was the main alternative splice variant for 8 genes because of its higher expression levels but splice variant 2 was also an important variant existing individually. The expression of splice variants in a gene was regulated by nitrogen $(\mathrm{N})$ and the expression of 5 genes was up-regulated at higher concentration of all forms of $\mathrm{N}$ and that of nine genes was up-regulated at higher nitrate concentration. The mRNA levels of splice variants were also regulated during leaf and panicle development of rice. It indicated that alternative splice variants of $O s A A T$ family were regulated with a natural variation in expression ratio grown under various nitrogen conditions in rice. (C) 2017 Friends Science Publishers
\end{abstract}

Keywords: Amino acid transporter; Rice; Alternative splicing; Expression profile; Nitrogen; Development

\section{Introduction}

Inorganic nitrogen $(\mathrm{N})$ is mainly absorbed in the form of nitrate and ammonium. It is converted to amino acids directly in the roots or after translocation to the leaves. The amino acids are then transported to the roots, leaves, flowers, pollens and embryos. Amino acids require transporters from source to sink organs (Coruzzi and Bush, 2001; Tegeder, 2012) and amino acid transporters (AATs) are cellular membrane proteins for their transport. They play a critical role in different processes of plants such as seed development, abiotic and pathogen stresses (Schulze et al., 1999; Paungfoo-Lonhienne et al., 2008; Näsholm et al., 2009). More than 60 AtAATs have been identified in Arabidopsis (Andrews et al., 2009) and more than 80 in rice (Lu et al., 2012; Zhao et al., 2012).

Plant AAT family includes amino acid/auxin permease (AAAP) family and the APC family (Marschnert et al., 1997). The AAAP family includes amino acid permeases (AAPs), aromatic and neutral amino acid transporters (ANTs), proline transporters (ProTs), auxin transporters (AUXs), lysine and histidine transporters (LHTs) and $\gamma$ aminobutyric acid transporters (GATs). APC family includes amino acid/choline transporters, cationic amino acid transporters and polyamine $\mathrm{H}^{+}$-symporters (Fischer et al., 1998; Gillissen et al., 2000; Ortiz-Lopez et al., 2000).

The $A A T$ gene family members have been identified in Arabidopsis (Tegeder, 2012), rice (Lu et al., 2012), poplar (Wu et al., 2015), Solanum tuberosum L. (Ma et al., 2016) and Glycine max L. (Cheng et al., 2016). This showed that AAP transporters play an important role in loading of amino acids for nitrogen sink and supply (Tegeder and Ward, 2012). AtAAP1 regulates amino acid transport to the root cells or embryos (Lee et al., 2007; Sanders, 2009). Furthermore, this transporter functions in the uptake of glutamate and neutral amino acids when present at soil concentrations in Arabidopsis (Perchlik et al., 2014). AtAAP2 localizes to the phloem and plays a major role in $\mathrm{N}$ transfer from the xylem to phloem (Zhang et al., 2010). AtAAP3 is preferentially expressed in the vascular tissue of root (Okumoto et al., 2004). AtAAP5 transports amino acids at low concentrations in the roots (Svennerstam et al., 2008) and AtAAP6 regulates amino acid composition of the phloem (Hunt et al., 2010). AtAAP8 transports amino acids to the endosperm during early embryogenesis (Schmidt et al., 2007). Recently, AtAAP8 is shown to be localized in the

To cite this paper: Fang, Z., Q. Zeng, K. Lv, W. Huang and M. Zhang, 2017. Differential expression pattern of splice variants of amino acid transporter genes from rice grown under various nitrogen conditions and during development. Int. J. Agric. Biol. 19: 1246-1258 
plasma membrane and functions in phloem loading (Santiago and Tegeder, 2016). AtLHT1 plays a role in cellular amino acid uptake in root epidermis and leaf mesophyll (Hirner et al., 2006). AtProTs are responsible for the transport of proline, glutamic acid, glycine betaine and gamma-aminobutyric acid (GABA; Grallath, 2005). AtGATl is highly expressed at higher GABA concentration or in the event of wounding and senescence and the protein it encodes is a high-affinity transporter for GABA (Meyer $e t$ al., 2006). AtANT1 transports aromatic and neutral amino acids such as arginine (Chen et al., 2001). AtAUX1 could facilitate auxin uptake and regulates the root gravitropism (Bennett et al., 1996; Marchant et al., 1999). Although the functions of many AATs in Arabidopsis have been identified, few studies have investigated the AAT family members in rice. Whole genome analysis suggested the presence of 85 or 79 AAT homologous genes in rice (Lu et al., 2012; Zhao et al., 2012). The biomass and yield of rice is significantly influenced when some of the OsAAT genes are knocked out (Lu et al., 2012; Peng et al., 2014).

Alternative splicing of gene's post transcription can allow novel ways to increase the diversity of mRNAs (Graveley, 2001; Kriventseva et al., 2003). Alternative splicing is divided into 7 types: alternative donor, alternative acceptor, alternative terminal exon, skipped exon/retained exon, initiation within an intron, termination within an intron and retained intron/spliced intron (Campbell et al., 2006; Wang and Brendel, 2006).

The roles of the $A A T$ genes in plants, especially in rice are not known completely and diverse alternative splicing regulation might be important for $\mathrm{N}$ uptake and utilization. In this study, we analysis 11 alternative-splicing genes of the rice $O S A A T$ family and uncover alternative splicing diversification of these genes by conducting bioinformatics and expression regulation.

\section{Materials and Methods}

\section{Identification of $O s A A T$ Alternative Splicing Genes}

The OsAAT family gene sequences were acquired from Rice Genome Annotation Project (http://rice.plantbiology.msu.edu/) and the alternativesplicing genes were predicted. These full-length corresponding alternative splicing mRNA sequences were checked from the Rice Annotation Project (http://rapdb.dna.affrc.go.jp/).

\section{Protein Structure and Phylogenetic Analysis of OSAAT Alternative Splicing Genes}

Chemical properties of the proteins were analyzed using Protparam (http://web.expasy.org/protparam/). Their subcellular localization was predicted using Wolf PSORT (http://psort.hgc.jp/) and transmembrane domains were $\begin{array}{lllll}\text { analyzed using TMHMM } & \text { Server } & & \\ & \text { V. } & \end{array}$ (http://www.cbs.dtu.dk/services/TMHMM/).

\section{Rice Materials and Treatments}

For expression analysis of the $O S A A T$ alternative-splicing genes under normal conditions, total RNA of Zhonghua 11 (ZH11) was extracted from the different tissues of rice plants grown in a controlled field of Wuhan Institute of Bioengineering. For $\mathrm{N}$ treatments, rice seeds were soaked in water and germinated at $28^{\circ} \mathrm{C}$ for 2 days and then cultured in basic nutrient solution (Yoshida et al., 1976) with one of the following as the $\mathrm{N}$ source: $0.5 \mathrm{mM} \mathrm{KNO}{ }_{3}, 2.0 \mathrm{mM}$ $\mathrm{KNO}_{3}, 5.0 \mathrm{mM} \mathrm{KNO}{ }_{3}, 0.25 \mathrm{mM}\left(\mathrm{NH}_{4}\right)_{2} \mathrm{SO}_{4}, 1 \mathrm{mM}$ $\left(\mathrm{NH}_{4}\right)_{2} \mathrm{SO}_{4}, 2.5 \mathrm{mM}\left(\mathrm{NH}_{4}\right)_{2} \mathrm{SO}_{4}, 0.25 \mathrm{mM} \mathrm{NH}_{4} \mathrm{NO}_{3}, 1 \mathrm{mM}$ $\mathrm{NH}_{4} \mathrm{NO}_{3}$ or $2.5 \mathrm{mM} \mathrm{NH} \mathrm{NO}_{3}$.

\section{RNA Extraction and Quantitative Real-time Polymerase Chain Reaction Analysis}

Total RNA was extracted using Trizol reagent according to the manufacturer's instructions (Invitrogen, China). The first-strand of cDNA was synthesized from $3 \mu \mathrm{g}$ of total RNA treated with DNase I by using M-MLV reverse transcriptase (Promega, China). The first-strand cDNA was used as a template for full-length cDNA PCR amplification and for real-time quantitative reverse transcriptasepolymerase chain reaction (qRT-PCR) after normalizing to rice Actinl (AB047313). The full-length cDNA-PCR amplification was performed in a $20 \mu \mathrm{L}$ reaction volume containing $1 \times$ PCR buffer, $1.0 \mu \mathrm{M}$ dNTPs, $1 \mu \mathrm{L}$ cDNA solution, $1.0 \mu \mathrm{M}$ gene-specific primers and $0.5 \mathrm{U}$ Taq polymerase (Takara, China) under the following conditions: $94^{\circ} \mathrm{C}$ for $3 \mathrm{~min}(1 \mathrm{cycle}) ; 94^{\circ} \mathrm{C}$ for $30 \mathrm{~s}, 55^{\circ} \mathrm{C}$ for $30 \mathrm{~s}$ and $72^{\circ} \mathrm{C}$ for $90 \mathrm{~s}$ ( 40 cycles) and $72^{\circ} \mathrm{C}$ for $10 \mathrm{~min}$ ( 1 cycle). The primers for transcription level detection of these splice variants were designed by using different open reading frame (ORF), 5'UTR or 3'UTR sequences between splice variants in a gene. If the shorter-splice variant had fewer exons than the longer-splice variant the primers were designed for the common sequences between the two splice variants. Next, one of the two splice variants accounts for half of the expression level for both the splice variants. The positions of primers for amplification in qRT-PCR are shown as red arrows in Fig. 1. The qRT-PCR analysis was performed in a $20 \mu \mathrm{L}$ reaction volume containing $1 \times \mathrm{PCR}$ buffer, $0.25 \mu \mathrm{M}$ dNTPs, $1 \mu \mathrm{L}$ cDNA solution, $1.0 \mu \mathrm{M}$ genespecific primers and 0.5 U Taq polymerase (Takara, China) under the following conditions: $94^{\circ} \mathrm{C}$ for $2 \mathrm{~min}$ ( 1 cycle); $94^{\circ} \mathrm{C}$ for $30 \mathrm{~s}, 55^{\circ} \mathrm{C}$ for $30 \mathrm{~s}$ and $72^{\circ} \mathrm{C}$ for $30 \mathrm{~s}$ (40 cycles) and $72^{\circ} \mathrm{C}$ for $1 \mathrm{~min}$ ( 1 cycle).

\section{Results}

\section{Identification of Alternative Splice Variants from Rice AAT Gene Family}

In all, $85 A A T$ genes (OsAATs) are known to be present in the rice (Oryza sativa L.) genome. The alternative splicing genes from this family were identified by assessing all the 
members of the OsAAT family by searching the Rice Genome Sequence Annotation (http://rice.plantbiology.msu.edu/). Eleven putative alternative splicing OsAAT genes were found; they were predicted to produce a total of 24 alternatively spliced mRNAs that have 23 different ORFs (Table 1). The exon number of the 11 OsAAT genes ranged from 3 to 12 (Fig. 1). Eleven $O s A A T$ s were classified into 5 kinds of alternative splicing types (Campbell et al., 2006). Two genes (OsATL7 and $O s A A P 5)$ belonged to the kind that showed initiation within an intron; four (OsAUX1, OsProT3, OsAAP1 and OsAAP4), alternative acceptors; two (OsProT1 and OsAUX2), skipped exon/retained exon; one (OsATL4), retained intron/spliced intron; and two (OsAAP13 and OsATL4), termination within an intron. Two kinds of alternative splicing types were identified for OsAAP4 and OsATLA.

The corresponding mRNAs for the putative alternative splicing mRNAs were determined by checking the fulllength mRNA sequences from the Rice Annotation Project (http://rapdb.dna.affrc.go.jp/); 17 kinds of mRNAs were found in this database except seven mRNAs of OsAAP4-2, OsAAP4-3, OsAAP5-2, OsAAP13-2, OsAAP14-2, OsProT12 and OsProT3-2. Further, 23 full-length cDNA ORFs of splice variants (OsATL7-1, OsATL7-2, OsAUX1-1, OsAUX1-2, OsAAP5-1, OsAAP5-2, OsProT1-1, OsProT12, OsAAP13-1, OsAAP13-2, OsAAP14-1, OsAAP14-2, OsAUX2-1, OsATL4-1, OsATL4-2, OsATL4-3, OsProT3-1, OsProT3-2, OsAAP1-1, OsAAP1-2, OsAAP4-1, OsAAP4-2 and $O S A A P 4-3)$ were amplified using PCR by using the RTPCR cDNA template (Fig. 2). Thus, the splice variants were identified. Twenty four alternative splicing mRNAs of the 11 OsAAT genes were predicted to encode 23 kinds of proteins that had 229 to 574 amino acids residues (Table 2). Their predicted proteins belonged to AAT-like, auxin transporter, amino acid permease or proline transporter. These splice variant proteins were predicted to be localized at the membrane and contained 5 to 12 transmembrane helices; different transmembrane helices were present between splice variants in one splicing gene except $O s A A P 1$ (Fig. 3; Table 3). However, one splice variant (OsAAP4-3) had no transmembrane helices; this could be because of the recombination of exons, causing remarkable changes in amino acids (Table 4).

To further confirm the phylogenetic relationship of the proteins encoded by the $O S A A T$ alternative splice variants, we compared their amino acid sequences (Fig. 4). The analysis of phylogenetic relationship revealed that 10 alternative splicing proteins, including OsAAP1 (OsAAP11 and OsAAP1-2), OsAAP4 (OsAAP4-1 and OsAAP4-2), OsAAP5 (OsAAP5-1 and OsAAP5-2), OsAAP13 (OsAAP13-1 and OsAAP13-2) and OsAAP14 (OsAAP14-1 and OsAAP14-2) were clustered into the AAP subfamily; four alternative splicing proteins, including OsAUX1 (OsAUX1-1 and OsAUX1-2) and OsAUX2 (OsAUX2-1 and OsAUX2-2) were clustered into the AUX subfamily; four alternative splicing proteins, including OsProT1 (OsProT1-1 and OsProT1-2) and OsProT3 (OsProT3-1 and OsProT3-2) were clustered into the ProT subfamily; and five alternative splicing proteins, including OsATL4 (OsATL4-1, OsATL4-2 and OsATL4-3) and OsATL7 (OsATL7-1 and OsATL7-2) were clustered into the ATL subfamily. However, the protein OsAAP4-3 was not clustered into the AAP subfamily.

\section{Root Expression Pattern of OsAAT Alternative Splicing Genes under Various Nitrogen Conditions}

Root is the main organ for the uptake of $\mathrm{N}$ as well as amino acids. The comprehensive roles of the alternative splicing mRNA variants of the $O S A A T$ genes in response to various $\mathrm{N}$ levels in rice roots were determined by their expression patterns when using inorganic $\mathrm{N}\left(\mathrm{NO}_{3}{ }^{-}, \mathrm{NH}_{4}{ }^{+}\right.$or $\left.\mathrm{NH}_{4} \mathrm{NO}_{3}\right)$ as the sole $\mathrm{N}$ source by using qRT-PCR (Fig. 5; all primer sequences used in this study are listed in Table 5). When the difference in the expression of the alternatively spliced mRNAs within a gene was compared, higher level of the first spliced mRNA variants was noted for OsAAP5, OsAAP13, OsAUX2, OsATL4, OsProT3, OsAAP1, OsAAP4 and higher levels of the second spliced mRNA variants were found for OsATL7, OsProT1 and OsAAP14. This indicated that the spliced mRNA variants for a gene differed in response to $\mathrm{N}$ availability. Two spliced mRNA variants of only one gene $(O s A U X 1)$ were expressed at a similar level (Fig. 5B).

Roots subjected to nitrate treatment showed the upregulation of thirteen alternative splice variants of nine genes (OsATL7-2, OsAUX1-1/2, OsAAP5-1/2, OsAAP14-2, OsAUX2-1, OsATL4-1, OsProT3-1, OsAAP1-1 and OsAAP4-1/2/3) and only one gene (OsAAP13-1) showed down-regulation of the alternative splice variant (Fig. 5). After treatment with ammonium, 11 alternative splice variants of nine genes (OsATL7-2, OsAUX1-2, OsAAP5-1, OsAAP14-1/2, OsAUX2-1/2, OsATL4-1, OsProT3-1, $O s A A P 1-1$ and $O s A A P 4-3)$ were up-regulated and three alternative splice variants of 3 genes (OsAUX1-1, OsAAP13-1 and OsAAP4-1) were down-regulated. After nitrate ammonium treatment, seven alternative splice variants of six genes (OsATL7-2, OsAUX1-1, OsAAP5-1, $A U X 2-1 / 2$, OsATL4-1 and OsAAP4-1) were up-regulated and two alternative splice variants of two genes (OSAAP131 and $O s A A P 4-3)$ were down-regulated. Interestingly, the expression of $O S A U X 1-1$ and $O S A A P 4-1 / 2$ was up-regulated after nitrate treatment, but down-regulated after ammonium or nitrate ammonium treatment.

\section{Leaf Expression Pattern of $O s A A T$ Alternative Splice Genes under Various Nitrogen Conditions}

The leaf expression pattern of the $O s A A T$ alternative splice variants in response to various $\mathrm{N}$ levels was investigated after inorganic $\mathrm{N}$ treatment $\left(\mathrm{NO}_{3}{ }^{-}, \mathrm{NH}_{4}{ }^{+}\right.$or $\left.\mathrm{NH}_{4} \mathrm{NO}_{3}\right)$ by 
Table 1: Information of rice alternative splicing amino acid transporter genes (OsAATs)

\begin{tabular}{|c|c|c|c|c|c|c|}
\hline \multicolumn{2}{|c|}{ Gene name } & \multirow[t]{2}{*}{ Transcript ID in $\mathrm{MSU}^{\mathrm{c}}$} & \multirow[t]{2}{*}{ Transcript ID in RAP } & \multirow{2}{*}{$\begin{array}{l}\text { No. } \\
\text { Introns }\end{array}$} & \multirow[t]{2}{*}{ of No. of Exons } & \multirow[t]{2}{*}{ Predicted function } \\
\hline by Lu et al. (2012) & by Zhao et al. (2012) & & & & & \\
\hline OsAAT7-1 & OsATL7-1 & LOC_Os01g61044.1 & AK064301 & 4 & 5 & Amino acid transporter-like \\
\hline OsAAT7-2 & OsATL7-2 & LOC_Os01g61044.2 & AK102220 & 4 & 5 & Amino acid transporter-like \\
\hline OsAAT9-1 & OsAUX1-1 & LOC_Os01g63770.1 & AK103239 & 6 & 7 & Auxin transporter \\
\hline OsAAT9-2 & OsAUX1-2 & LOC_Os01g63770.2 & AK068536 & 3 & 4 & Auxin transporter \\
\hline OsAAT12-1 & OsAAP5-1 & LOC_Os01g65660.1 & AK073884 & 5 & 6 & Amino acid permease \\
\hline OsAAT12-2 & OsAAP5-2 & LOC_Os01g65660.2 & Not found & 3 & 4 & Amino acid permease \\
\hline OsAAT16-1 & OsProT1-1 & LOC_Os01g68050.1 & AK241733 & 6 & 7 & Proline transporter \\
\hline OsAAT16-2 & OsProTl-2 & LOC_Os01g68050.2 & Not found & 4 & 5 & Proline transporter \\
\hline OsAAT35-1 & OSAAP13-1 & LOC_Os04g39489.1 & AK071044 & 6 & 7 & Amino acid permease \\
\hline OsAAT35-2 & OsAAP13-2 & LOC_Os04g39489.2 & Not found & 3 & 4 & Amino acid permease \\
\hline OsAAT40-1 & OsAAP14-1 & LOC_Os04g56470.1 & XM_0157786001 & 6 & 7 & Amino acid permease \\
\hline OsAAT40-2 & OsAAP14-2 & LOC_Os04g56470.2 & Not Found & 5 & 6 & Amino acid permease \\
\hline OsAAT45-1 & OsAUX2-1 & LOC_Os05g37470.1 & AK111659 & 5 & 6 & Auxin transporter \\
\hline OsAAT45-2 & OsAUX2-2 & LOC_Os05g 37470.2 & AK111849 & 6 & 7 & Auxin transporter \\
\hline OsAAT51-1 & OsATLA-1 & LOC_Os06g16420.1 & AK120497 & 4 & 5 & Amino acid transporter-like \\
\hline OsAAT51-2 & OsATLA-2 & LOC_Os06g16420.2 & AK066102 & 3 & 4 & Amino acid transporter-like \\
\hline OsAAT51-3 & OsATLA-3 & LOC_Os06g16420.3 & AK099920 & 2 & 3 & Amino acid transporter-like \\
\hline OsAAT58-1 & OsProT3-1 & LOC_Os07g01090.1 & AK066298 & 6 & 7 & proline transporter \\
\hline OsAAT58-2 & OsProT3-2 & LOC_Os07g01090.2 & Not found & 5 & 6 & Proline transporter \\
\hline OSAAT60-1 & OSAAP1-1 & LOC_Os07g04180.1 & AK106110 & 5 & 6 & Amino acid permease \\
\hline OsAAT60-2 & OsAAP1-2 & LOC_Os07g04180.2 & AK103862 & 4 & 5 & Amino acid permease \\
\hline OsAAT72-1 & OsAAP4-1 & LOC_Os12g09300.1 & AK069508 & 4 & 5 & Amino acid permease \\
\hline OsAAT72-2 & OsAAP4-2 & LOC_Os12g09300.2 & Not found & 3 & 4 & Amino acid permease \\
\hline OsAAT72-3 & OsAAP4-3 & LOC_Os12g09300.3 & Not found & 2 & 3 & Amino acid permease \\
\hline
\end{tabular}

Table 2: Protein information of rice alternative splicing amino acid transporter genes (OsAATs)

\begin{tabular}{|c|c|c|c|c|c|}
\hline Gene name & $\begin{array}{l}\text { Amino acid } \\
\text { number }\end{array}$ & $\begin{array}{l}\text { Molecular } \\
\text { weight (D) }\end{array}$ & $\begin{array}{l}\text { Theoretical } \\
\text { pI }\end{array}$ & Localization & \\
\hline OsATL7-1 & 459 & 47870.3 & 9.43 & Membrane & \\
\hline OsATL7-2 & 456 & 47688.0 & 7.73 & Membrane & \\
\hline OsAUX1-1 & 492 & 54762.1 & 8.27 & Membrane & \\
\hline OsAUX1.2 & 282 & 31354.3 & 9.26 & Membrane & \\
\hline OsAAP5-1 & 465 & 50002.3 & 8.87 & Membrane & \\
\hline OsAAP5-2 & 375 & 40484.6 & 9.08 & Membrane & \\
\hline OsProT1-1 & 447 & 49025.0 & 9.20 & Membrane & \\
\hline OsProT1-2 & 354 & 38484.6 & 8.60 & Membrane & \\
\hline OsAAP13-1 & 466 & 50747.0 & 8.38 & Membrane & \\
\hline OsAAP13-2 & 229 & 24339.0 & 7.07 & Membrane & \\
\hline OsAAP14-1 & 469 & 51377.9 & 8.89 & Membrane & \\
\hline OsAAP14-2 & 409 & 44980.4 & 9.60 & Membrane & \\
\hline OsAUX2-1 & 503 & 47688.0 & 7.73 & Membrane & \\
\hline OsAUX2-2 & 482 & 53358.3 & 8.77 & Membrane & \\
\hline OsATL4-1 & 448 & 48121.6 & 6.79 & Membrane & \\
\hline OsATL4-2 & 402 & 43002.5 & 6.23 & Membrane & \\
\hline OsATL4-3 & 274 & 29277.6 & 6.29 & Membrane & \\
\hline OsProT3-1 & 434 & 47663.9 & 9.30 & Membrane & \\
\hline OsProT3-2 & 384 & 42329.0 & 9.69 & Membrane & \\
\hline OsAAP1-1 & 487 & 52864.1 & 8.80 & Membrane & \\
\hline OsAAP1-2 & 460 & 49716.9 & 9.15 & Membrane & \\
\hline OsAAP4-1 & 468 & 50891.3 & 8.52 & Membrane & \\
\hline OsAAP4-2 & 341 & 36748.3 & 6.69 & Membrane & \\
\hline OsAAP4-3 & 371 & 43411.0 & 12.26 & $\begin{array}{l}\text { Nucl: } 9.0, \\
\text { 3.0, Plas: } 1.0\end{array}$ & Cyto: \\
\hline
\end{tabular}

Nucl: Nucleus, Cyto: Cytoplasm, Plas: Plastid

using qRT-PCR (Fig. 6). When the difference in the expression of the alternatively spliced mRNAs within a gene was compared, higher level of the first spliced mRNA variant was found in OsAAP5, OsAAP13, OsAUX2,
OsProT3, OsAAP1, OsAAP4 and higher levels of the second spliced mRNA variants were found in OsATL7, OsProT1 and OsAAP14. The spliced mRNA variants of only two genes $(O S A U X 1$ and $O S A T L 4)$ were expressed at a similar level (Fig. 6B, H). OsAUX2-3, OsATL4-2 and OsATL4-3 showed higher expression in the leaves (Fig. 6G, H). Although OsAUX2-3 has the same ORF as that of OsAUX22 , the expression level of $O s A U X 2-3$ was significantly different from that of $O s A U X 2-2$ in the leaves when different 3 '-untranslated regions were used as primers for qRT-PCR. Different mRNAs of alternatively spliced OSAAT genes were shown to exist either in rice roots or in leaves in response to various $\mathrm{N}$ concentrations.

In leaves subjected to nitrate treatment (Fig. 6) the expression of OsATL7-2, OsProT1-1/2, OsAUX2-1 and OsAAP4-1 was up-regulated and that of OSATL7-2, OsAAP13-1, OsALT4-1/2 and OsAAP1-1 was downregulated. After ammonium treatment the expression of OsProT1-1 and OsAAP4-1 was up-regulated, but that of OsATL7-2, OsAAP13-1, OsATL4-2/3 and OsAAP1-1 was down-regulated. After nitrate ammonium treatment, the expression of OsProTl-1 was up-regulated, but that of OsAAP1-1 was down-regulated.

\section{Leaf Expression Pattern of $O s A A T$ Alternative Splicing Genes at the Reproductive Stage}

Systematic characterization of the participation of $O S A A T$ splicing genes in leaf amino acid transport or mobilization was performed by conducting qRT-PCR by using leaf 


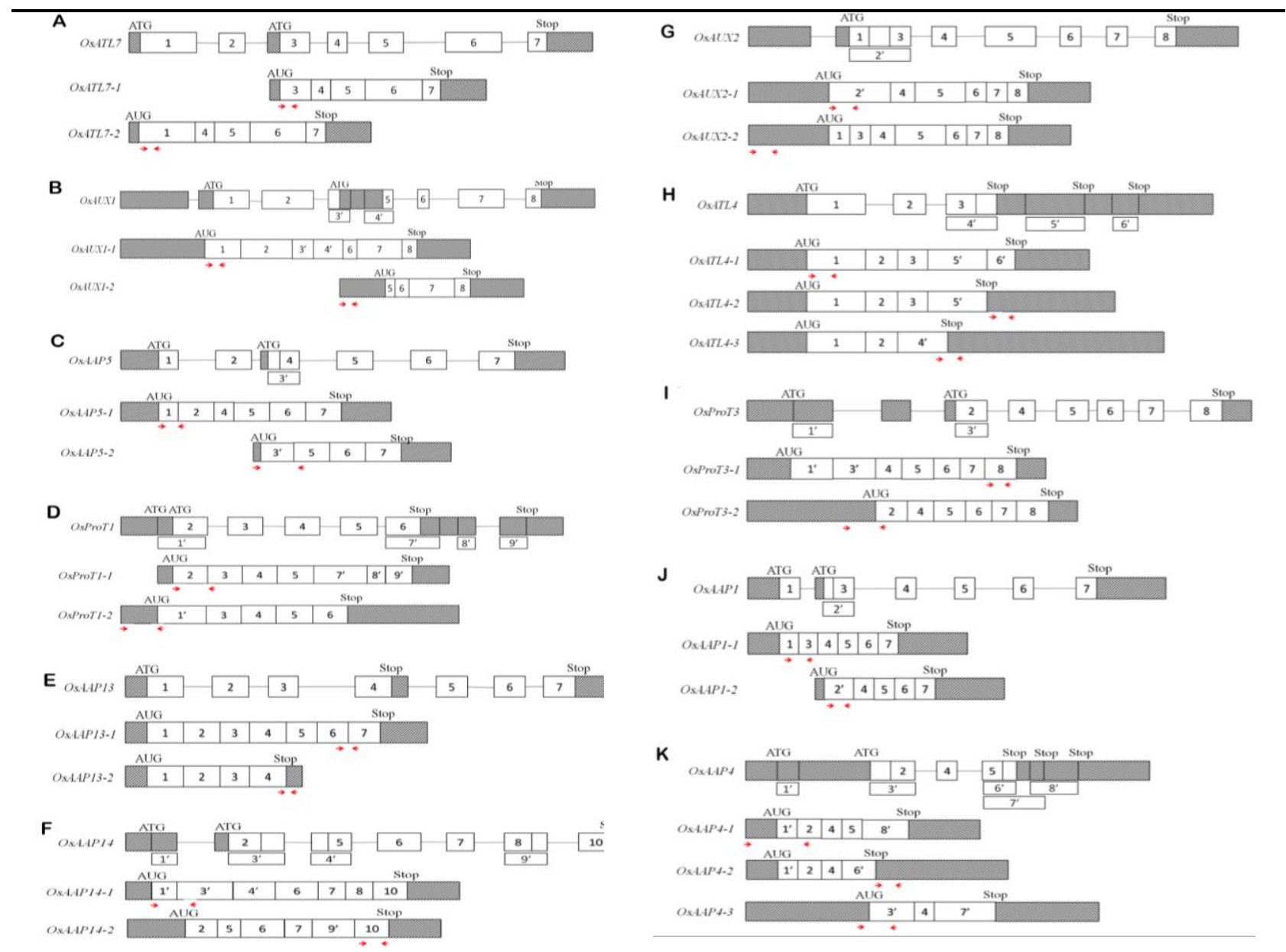

Fig. 1: Alternative splice variant structure of $O s A A T$ genes. $O s X X$ represents the DNA sequence of splice variants. $O s X X-1, O s X X-2, O s X X-3$ represent mRNA sequences of each splice variant. The OsAAT splice variant sequences were acquired from http://rice.plantbiology.msu.edu/ and selected from the predicted alternative splice variants. Gray box represents UTR. White box represents a potential exon region for splice variants. Black line represents potential intron region for splice variants. Red arrow represents the position site of forward and reverse primers for the detection of the expression level of splice variants in qRT-PCR

tissues during the entire reproductive stage (Fig. 7). The results indicated that the expression levels were different among splice variants within a gene of most $O S A A T$ splicing genes (OsAUX1, OsAAP5, OsProT1, OsAAP13, OsProT3, OsAAP1, OsAAP14 and OsAAP4) at four stages. The expression of splice variant 1 was higher than that of splice variant 2 for six splicing genes (OsAUX1, OsAAP5, OsProT1, OsAAP13, OsProT3 and OsAAP1); however, the expression of splice variant 1 was lower than that of splice variant 1 for two splicing genes OsAAP14 and OsAAP4. Only three genes OsATL7, OSAUX2 and OSATL4 showed similar expression among different alternative splice variants. The expression of OsATL7-1/2, OsAUX1-1/2, OsAAP5-1, OsProT1-1, OsAAP14-2, OsProT3-1 and $O s A A P-1$ was up-regulated in the leaves from the early booting stage to mature stage, but that of OSAAP13-1 was down-regulated along with development (Fig. 7E).

\section{Panicle Expression Pattern of OsAAT Alternative Splicing Genes at the Reproductive Stage}

In this study, qRT-PCR was used to monitor the expression changes of the 24 alternative splicing mRNAs in developing panicles (Fig. 8). The first alternatively spliced variants of OsAAP5, OsAAP13, OsAUX2 and OsProT3, but the second alternatively spliced variants of OsAAP4 and OsAAPI4 were highly expressed in the panicles. Further, qRT-PCR showed that OsATL7-1, OSAAP5-1, OsProT1-1 and OsAAP1-1 were highly expressed highest in the early developing panicles (P1); OsAAP13-1, OsAAP14-2, OsAUX2-1, OsATL4-2/3 and OSAAP1-2 showed the highest expression level in the middle developing panicles (P2-P3); and $O S A A P 4-1 / 2$ showed the highest expression level in mature panicles (P4). 
Expression Pattern of AAT Splice Variants in Rice / Int. J. Agric. Biol., Vol. 19, No. 5, 2017

Table 3: List of the full-length cDNA PCR amplified primers used in this study

\begin{tabular}{|c|c|c|}
\hline Name & Sequence $\left(5^{\prime}-3^{\prime}\right)$ & Note \\
\hline OsATL7-1-OF & ATGGTGTCCAAGAAGACCTCCATC & The PCR fragment is $1380 \mathrm{bp}$ \\
\hline OsATL7-1-OR & СТACCTACCTGCGGCATGGCCTCC & \\
\hline OsATL7-2-OF & ATGACGCCGCCGGCGAGCACGGGC & The PCR fragment is $1371 \mathrm{bp}$ \\
\hline OsATL7-2-OR & CTACCTACCTGCGGCATGGCCTCC & \\
\hline OsAUX1-1-OF & ATGGTGCCGCGCGAGCAGGCGGAG & The PCR fragment is $1479 \mathrm{bp}$ \\
\hline OsAUX1-1-OR & CTAGTGGTGCGGCAATGGCACCGG & \\
\hline OsAUX1-2-OF & ATGACCACCTATACCGCTTGGTAC & The PCR fragment is $849 \mathrm{bp}$ \\
\hline OsAUX1-2-OR & CTAGTGGTGCGGCAATGGCACCGG & \\
\hline OsAAP5-1-OF & ATGAACAAGAACGCCGCACCGGAA & The PCR fragment is $1398 \mathrm{bp}$ \\
\hline OsAAP5-1-OR & GCTGACAGTTTTGAAAGGGGTTGCAAC & \\
\hline OsAAP5-2-OF & ATGAACAAGAACGCCGCACCGGAA & The PCR fragment is $1128 \mathrm{bp}$ \\
\hline OsAAP5-2-OR & ATGCCAAAAATATTTTCAGGTCCT & \\
\hline OsProT1-1-OF & ATGGCTGCTTCATCGCTCGACGCCGAG & The PCR fragment is $1344 \mathrm{bp}$ \\
\hline OsProT1-1-OR & TTACATGTCCGCGAAGAAATGGTA & \\
\hline OsProT1-2-OF & ATGAAGTGTGCGTGTGTGAGAGAGT & The PCR fragment is $1065 \mathrm{bp}$ \\
\hline OsProT1-2-OR & TCACGCCATCAACGGGGAGGAGGA & \\
\hline OsAAP13-1-OF & ATGGCGCTCGGCGACGGGGACGAC & The PCR fragment is $1401 \mathrm{bp}$ \\
\hline OsAAP13-1-OR & TTAGCCTAGCTTCTGGCTGATGAG & \\
\hline OsAAP13-2-OF & ATGGCGCTCGGCGACGGGGACGAC & The PCR fragment is $690 \mathrm{bp}$ \\
\hline OsAAP13-2-OR & TCAAAGCCTCAAAGGATGAACAGA & \\
\hline OsAAP14-1-OF & ATGGCGCCGCAGCTGCCGCTCGAG & The PCR fragment is $1410 \mathrm{bp}$ \\
\hline OsAAP14-1-OR & CTAGCCAAGCCTCTTTCTGATGAC & \\
\hline OsAAP14-2-OF & ATGGACGTGCGTAGCGCACATTAT & The PCR fragment is $1230 \mathrm{bp}$ \\
\hline OsAAP14-2-OR & CTAGCCAAGCCTCTTTCTGATGAC & \\
\hline OsAUX2-OF & ATGGTGCCGGCCGGCGACCAGGCG & The PCR fragment is $1512 \mathrm{bp}$ \\
\hline OsAUX2-OR & CTAGTGGCGCGGCGGAGCCGGCAG & \\
\hline OsATL4-1-OF & ATGGGTGGAGGCGTCACGGAGCGG & The PCR fragment is $1347 \mathrm{bp}$ \\
\hline OsATL4-1-OR & TCAGGCTATGGAAGGGGAACTTTTCC & \\
\hline OsATL4-2-OF & ATGGGTGGAGGCGTCACGGAGCGG & The PCR fragment is $1209 \mathrm{bp}$ \\
\hline OsATL4-2-OR & TTACCTTAGAGTGATCGCGGCTGG & \\
\hline OsATL4-3-OF & ATGGGTGGAGGCGTCACGGAGCGG & The PCR fragment is $825 \mathrm{bp}$ \\
\hline OsATL4-3-OR & CTAAAAGAAAATTGAAAGAAAGTCTTC & \\
\hline OsProT3-1-OF & ATGAACATCGACATGGCCAATTCC & The PCR fragment is $1305 \mathrm{bp}$ \\
\hline OsProT3-1-OR & TCACAGATCAGCAAACAAATGGTA & \\
\hline OsProT3-2-OF & ATGGTCCCTTTAGGTTGGATTGGT & The PCR fragment is $1155 \mathrm{bp}$ \\
\hline OsProT3-2-OR & TCACAGATCAGCAAACAAATGGTA & \\
\hline OsAAP1-1-OF & CTAGCTAAGCTAGGAATTGAA & The PCR fragment is $1485 \mathrm{bp}$ \\
\hline OsAAP1-1-OR & TCATGAGGAGACGCTGAATGGCTT & \\
\hline OsAAP1-2-OF & CAAGCTAATGGGTTGGTAATAACA & The PCR fragment is $1407 \mathrm{bp}$ \\
\hline OsAAP1-2-OR & TCATGAGGAGACGCTGAATGGCTT & \\
\hline OsAAP4-1-OF & ATGGACAGGAGAGCAGTAGTGTAT & The PCR fragment is $1407 \mathrm{bp}$ \\
\hline OsAAP4-1-OR & TCAGTTGACAGTCTTGAAGGGTGC & \\
\hline OsAAP4-2-OF & ATGGACAGGAGAGCAGTAGTGTAT & The PCR fragment is $1026 \mathrm{bp}$ \\
\hline OsAAP4-2-OR & TCATCGTCGATCGCCGCCCGCCAT & \\
\hline OsAAP4-3-OF & ATGATGATGATGATGATGATGGTGATGATCAG & The PCR fragment is $1116 \mathrm{bp}$ \\
\hline OsAAP4-3-OR & TCACGTAGTAGGTCGCGTTGATGA & \\
\hline
\end{tabular}

\section{Discussion}

We found that 11 genes of the 85 or 79 OsAAT genes were alternatively spliced (Lu et al., 2012; Zhao et al., 2012). They could be classified into five kinds of alternative splicing patterns. The highest proportion $(31.25 \%)$ of their alternative splicing types was selective receptor sites (AA) and the second $(25 \%)$ was intron splicing/intron retention. The highest alternative splicing type (probability, 53.5\%) in rice was intron splicing and intron retention and the second (15.1\%) was selective receptor site (AA) (Wang et al., 2006). The amino acid residues of these spliced proteins ranged from 229 to 574 and the molecular weights and isoelectric potentials ranged from 24 to $63 \mathrm{KDa}$ and 5.57 to 12.26 , respectively (Table 2). OsAAPI has two splice variants and variant OsAAP1-1 transports both positively and neutral charged basic amino acids in rice (Taylor et al., 2015). Five OSAAPs of rice AAT family have splice variants and the number or length of trans-membrane helices differed between the splice variants of a gene. These findings suggest that some $O S A A P$ splice variants play a broad role in rice growth and development. AUX members could support specific regulatory inputs from different signals or different interactions (Reed, 2001). We indicated that both OsAUX1 and AtAUX2 have two splice variants and their expression levels differed between splice variants 
Fang et al. / Int. J. Agric. Biol., Vol. 19, No. 5, 2017

Table 4: Analysis of transmembrane domain in OsAAT splice variants proteins

\begin{tabular}{|c|c|c|c|c|c|c|c|c|c|c|c|c|}
\hline \multirow[t]{2}{*}{ Splice variants } & \multirow[t]{2}{*}{ Amount } & \multicolumn{11}{|c|}{ Start and end site of trans-membrane domain } \\
\hline & & TM1 & TM2 & TM3 & TM4 & TM5 & TM6 & TM7 & TM8 & TM9 & TM10 & TM11 \\
\hline OsATL7-1 & 11 & $39-61$ & $66-88$ & $114-136$ & $163-182$ & $194-216$ & $236-258$ & $271-293$ & $321-343$ & $363-385$ & $390-409$ & $422-444$ \\
\hline OsATL7-2 & 10 & $55-77$ & $115-137$ & $157-179$ & $191-213$ & $233-255$ & $268-290$ & $318-340$ & $360-382$ & $387-406$ & $419-441$ & \\
\hline OsAUX1-1 & 10 & $88-110$ & $149-171$ & $181-198$ & 203-225 & $240-262$ & 275-297 & $323-345$ & $365-382$ & $387-409$ & $438-460$ & \\
\hline OsAUX1-2 & 6 & $31-53$ & $66-88$ & $113-135$ & $155-172$ & $177-199$ & $228-250$ & & & & & \\
\hline OsAAP5-1 & 11 & $20-42$ & $52-74$ & $109-130$ & $150-172$ & 177-199 & $224-246$ & $267-289$ & 304-326 & 370-389 & $393-415$ & $427-449$ \\
\hline OsAAP5-2 & 9 & $21-40$ & $60-82$ & 87-109 & $134-156$ & $177-199$ & 214-236 & $280-299$ & $303-325$ & $337-359$ & & \\
\hline OsProT1-1 & 10 & $38-60$ & $67-89$ & $116-138$ & $159-181$ & $185-204$ & $225-247$ & $262-284$ & $351-370$ & 374-396 & $413-435$ & \\
\hline OsProT1-2 & 7 & $59-81$ & $85-107$ & 133-155 & $175-194$ & $201-223$ & 243-262 & $281-303$ & & & & \\
\hline OsAAP13-1 & 9 & $35-57$ & $59-81$ & $118-140$ & $160-182$ & $186-208$ & $276-298$ & $313-335$ & $393-415$ & $435-457$ & & \\
\hline OsAAP13-2 & 5 & $35-57$ & $59-81$ & $118-140$ & $160-182$ & $197-219$ & & & & & & \\
\hline OsAAP14-1 & 9 & $24-46$ & 53-75 & $114-136$ & $157-176$ & $180-202$ & $271-293$ & $308-330$ & $396-418$ & $438-460$ & & \\
\hline OsAAP14-2 & 8 & $43-65$ & $97-114$ & $121-143$ & $168-190$ & $211-233$ & $248-270$ & $336-358$ & $378-400$ & & & \\
\hline OsAUX2-1 & 11 & $66-85$ & $100-122$ & $161-183$ & $193-210$ & 215-237 & $252-274$ & 287-309 & $335-357$ & $377-394$ & $399-421$ & $441-463$ \\
\hline OsAUX2-2 & 10 & 79-101 & $140-162$ & $172-189$ & $194-216$ & $231-253$ & 266-288 & 314-336 & $356-373$ & $378-400$ & $420-442$ & \\
\hline OsATL4-1 & 11 & $31-53$ & $58-80$ & $111-133$ & $153-175$ & $182-204$ & $224-243$ & $254-286$ & $313-335$ & $355-377$ & $382-401$ & $414-436$ \\
\hline OsATL4-2 & 10 & $31-53$ & $58-80$ & $111-133$ & $153-175$ & $182-204$ & $224-243$ & $264-286$ & $313-335$ & $355-377$ & $382-401$ & \\
\hline OsATL4-3 & 6 & $31-53$ & $58-80$ & $111-133$ & $153-175$ & $182-204$ & $224-246$ & & & & & \\
\hline OsProT3-1 & 11 & $30-52$ & $56-78$ & $104-126$ & $141-163$ & $168-190$ & $210-232$ & $252-274$ & 289-311 & 339-358 & $362-384$ & $396-418$ \\
\hline OsProT3-2 & 10 & $5-27$ & $54-76$ & $91-113$ & $118-140$ & $160-182$ & $202-224$ & $239-261$ & 289-308 & $312-334$ & $346-368$ & \\
\hline OsAAP1-1 & 9 & $45-67$ & 71-93 & $130-152$ & 194-216 & 287-309 & $326-348$ & $391-410$ & $414-432$ & $452-474$ & & \\
\hline OsAAP1-2 & 9 & $7-29$ & $44-66$ & 103-125 & $167-189$ & $260-282$ & 299-321 & 364-383 & $387-405$ & $425-447$ & & \\
\hline OsAAP4-1 & 9 & $20-42$ & $49-71$ & $108-130$ & $142-164$ & $174-196$ & $265-287$ & $304-326$ & $384-406$ & $429-451$ & & \\
\hline OsAAP4-2 & 7 & $20-42$ & $49-71$ & $108-130$ & $142-164$ & 174-196 & $265-287$ & 297-319 & & & & \\
\hline
\end{tabular}

The OsAAT splice variants sequences was acquired from http://rice.plantbiology.msu.edu/) and the analysis of sequence of protein use TMHMM Server v. 2.0 (http://www.cbs.dtu.dk/services/TMHMM/

under exogenous N. AtAUXI was shown to regulate root gravitropism and change the distribution of indole-3-acetic acid to promote the formation of lateral roots (Bennett et al., 1996; Marchant et al., 1999). AtLAX3, an AtAUX1 homologous protein, could influence the lateral root prominence rate and regulate cell wall remodeling (Lee $e t$ al., 2011). Our results suggest that some OsAUX splice variants might play various roles in rice growth and development.

Amino acid transporters could transport a range of different types of amino acids in the roots directly (Miller $e t$ al., 2008; Svennerstam et al., 2008) or indirectly via other amino acids that are transferred from ammonium to glutamine by glutamine synthetase (Sonoda et al., 2003). Substrate specificity and expression profiles of AATs have been identified in Arabidopsis (Fischer et al., 1995). AAPs are highly regulated by environmental signals (Grallath $e t$ al., 2005). The PtAAT genes might play a critical role in abiotic stress signaling in Populus, because their expression was either increased or repressed after the PEG and cold treatments (Wu et al., 2015). However, little is known about the role of the OSAAT alternative splicing genes in response to environmental signal, especially $\mathrm{N}$ in the roots and leaves. We showed some clues about the role of OsAAT alternative splicing genes in response to $\mathrm{N}$ by determining their expression levels (Fig. 5 and 6). Splice variants for an OsAAT gene showed differential expression and responded differently to $\mathrm{N}$ in the rice roots and leaves. After nitrate, ammonium or ammonium nitrate treatments the alternative splice variants of OSAAT genes showed differential expression in the roots. Wide divergence of transmembrane

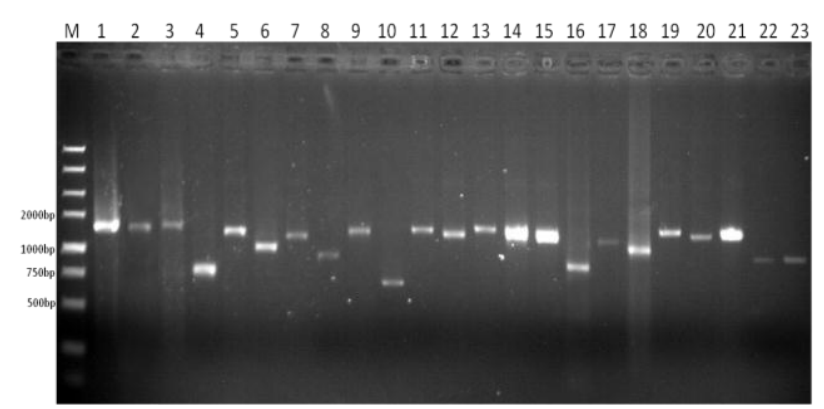

Fig. 2: The full-length cDNA amplification of $A A T$ splice variants. Lane 1: OsATL7-1, Lane 2: OsATL7-2, Lane 3: OsAUX1-1, Lane 4: OsAUX1-2, Lane 5: OsAAP5-1, Lane 6: OsAAP5-2, Lane 7: OsProT1-1, Lane 8: OsProT1-2; Lane 9: OsAAP13-1, Lane 10: OsAAP13-2, Lane 11: OsAAP14-1, Lane 12: OsAAP14-2, Lane 13: OsAUX2-1, Lane 14: OsATL4-1, Lane 15: OsATL4-2, Lane 16: OsATL4-3, Lane 17: OsProT3-1, Lane 18: OsProT3-2, Lane 19: OsAAP1-1, Lane 20: OsAAP1-2, Lane 21: OsAAP4-1, Lane 22: OsAAP4-2, Lane 23: OsAAP4-3

helices are noted in splice variants of OsAAP5, OsProT1, OsAAP13, OsAAP14, OsATL4, OsAAP4 and expression levels in response to $\mathrm{N}$ are different in the rice root and leaf. These findings suggest that $\mathrm{N}$ could regulate alternative splice variants of OSAAT genes, because of the divergence of protein structure in splice variants.

Some genes of the $A A T$ family have been characterized. It has shown different functions during the uptake of amino acids by the root, transporting amino acids 
Expression Pattern of AAT Splice Variants in Rice / Int. J. Agric. Biol., Vol. 19, No. 5, 2017

Table 5: List of the real-time quantitative RT-PCR primers used in this study

\begin{tabular}{|c|c|c|}
\hline Name & Sequence (5'-3') & Note \\
\hline OsATL7-1F & TGGTGTCCAAGAAGACCTCCAT & Detection of transcription level of OsATL7-1 \\
\hline OsATL7-1R & ACGACGCTCGTCGACACGTTG & \\
\hline OsATL7-2F & GTTCAACGTGTCGACGAGCATCAT & Detection of transcription level of $O S A T L 7-2$ \\
\hline OsATL7-2R & TACCGCAGCATGAATTCCACGGAG & \\
\hline OsAUX1-1F & AGGAGGCCATCGTGGCTGACA & Detection of transcription level of $O s A U X 1-1$ \\
\hline OsAUX1-1R & CGACCTGGTTAGAGGCGCAGCT & \\
\hline OsAUX1-2F & GTCACTTCGCAGCGCCAGTGTA & Detection of transcription level of $O s A U X 1-2$ \\
\hline OsAUX1-2R & GCTTGTCCAGCCGGTCGTTGA & \\
\hline OsAAP5-1F & AACGCCGCACCGGAAGACGT & Detection of transcription level of $O S A A P 5-1$ \\
\hline OsAAP5-1R & TAGGCGTTGGCGAGCAGAGT & \\
\hline OsAAP5-2F & CTTGTTGGTTAAACTGAACGC & Detection of transcription level of $O s A A P 5-2$ \\
\hline OsAAP5-2R & AACGCCAGCATGAGCACCGT & \\
\hline OsProT1-AF & TGGCTGCTTCATCGCTCGACG & Detection of both transcription level of OsProT1-1 and OsProT1-2 \\
\hline OsProT1-AR & CAACCCAGCGGCGCCATCAT & \\
\hline OsProT1-2F & ATGCGACCGAGCTACAATGCCGTC & Detection of transcription level of OsProT1-2 \\
\hline OsProT1-2R & TCGGCGTCGAGCGATGAAGC & \\
\hline OsAAP13-1F & GACTTCGCCAACGCCTGCAT & Detection of transcription level of $O S A A P 13-1$ \\
\hline OsAAP13-1R & CGCAGGAGGTTCACCCGACA & \\
\hline OsAAP13-2F & ATACCGGACTTCCACGACAT & Detection of transcription level of $O s A A P 13-2$ \\
\hline OsAAP13-2R & GCACTAGTACTACGACTGAGCA & \\
\hline OsAAP14-1F & ACCCACAACGCACCGGGAATCT & Detection of transcription level of OsAAP14-1 \\
\hline OsAAP14-1R & TCTCCGAGCCAGGAGACCTGTAGC & \\
\hline OsAAP14-AF & CCCGTCGAGATGTACTGCGTGCAG & Detection of both transcription level of OsAAP14-1 and OSAAP14-2 \\
\hline OsAAP14-AR & TTCCACCGAGCCGACGAACGCGAA & \\
\hline OsAUX2-1F & ACGACCAACCACGAACGACCTCGT & Detection of transcription level of $O s A U X 2-1$ \\
\hline OsAUX2-1R & ATCCCGAGCTGCGAGAAGGA & \\
\hline OsAUX2-AF & AGTCTCCTCACTCTCGACTACTCT & Detection of both transcription level of $O s A U X 2-1$ and $A U X 2-2$ \\
\hline OsAUX2-AR & TGCCACAGGAGGCTCGTCAT & \\
\hline OsAUX2-3F & TGCCTTTGTGTAGTAGGACAGC & Detection of transcription level of $O s A U X 2-3$ \\
\hline OsAUX2-3R & ACGACGCAAAGTTGCCAACAAC & \\
\hline OsATL4-1F & GCGCGGTGTTCAACCTGTCG & Detection of transcription level of OSATLA-1 \\
\hline OsATL4-1R & AGCTCGATGGAGGCGTCGGT & \\
\hline OsATL4-2F & CATTCCGAGCATCTGGGATGCCT & Detection of transcription level of $O S A T L 4-2$ \\
\hline OsATL4-2R & ACGGAATAAATATCCCAGCCA & \\
\hline OsATL4-3F & TGATGTTCCCGACTTGGCAT & Detection of transcription level of OSATLA-3 \\
\hline OsATL4-3R & AAGCAACCCTATTCGGGCTT & \\
\hline OsProT3-AF & TTGGCGACTTCATGAGCCTGA & Detection of both transcription level of OsProT3-1 and OsProT3-2 \\
\hline OsProT3-AR & TGCCAGGATATCTGCAAGGT & \\
\hline OsProT3-2F & AGTGAGGGTTCCCGAACACACCTC & Detection of transcription level of OsProT3-2 \\
\hline OsProT3-2R & GGATCAAGCCACATGTCCCACCAA & \\
\hline OsAAP1-1F & GCCTTCAACCTCGCCGAGTC & Detection of transcription level of $O S A A P 1-1$ \\
\hline OsAAP1-1R & GTTATGACCGAGAACGCCACCA & \\
\hline OsAAP1-2F & CGGACGAACACTTGGATGCA & Detection of transcription level of $O s A A P 1-2$ \\
\hline OsAAP1-2R & GTTATGACCGAGAACGCCACCA & \\
\hline OsAAP4-1,2F & TGGCACTCACCCTTGCACAC & Detection of both transcription level of OsAAP4-1 and OSAAP4-2 \\
\hline OsAAP4-1,2R & CCGTCCACACCGTCCCTTGT & \\
\hline OsAAP4-2,3F & TTGCTGCAGGTGTTCGCGCA & Detection of both transcription level of OsAAP4-2 and OsAAP4-3 \\
\hline OsAAP4-2,3R & ATCGTCCGCAGCACCAGCTTCAG & \\
\hline OsAAP4-3F & ACTTGAGCTCTCTGCATTGGGT & Detection of transcription level of $O S A A P 4-3$ \\
\hline OsAAP4-3R & AGCGGTAGCAATTGGCGAGGA & \\
\hline OsActin-F & CGGTGTCATGGTCGGAAT & Detection of transcription level of OsActin \\
\hline OsActin-R & GCTCGTTGTAGAAGGTGT & \\
\hline
\end{tabular}

into the phloem or partitioning of amino acids to the seeds (Tegeder, 2014). AtAAP1 transports amino acids at the roots of Arabidopsis (Lee et al., 2007) and regulates amino acids at developing embryos (Sanders et al., 2009). AtAAP6 affects the amino acid content of the Arabidopsis (Hunt et al., 2010). PtAAP11 is specifically expressed in xylem cells of poplar (Couturier et al., 2010). AtLHT1 could uptake amino acid both at the root epidermis and leaf mesophyll (Chen and Bush, 1997; Hirner et al., 2006). LeProT1 could transport proline, glycine betaine and GABA in tomato pollen (Schwacke et al., 1999).

During the reproductive stage, flag leaves develop from functional to senesce leaves, which are a source for amino acids and the sink of seeds (Fang et al., 2013). Rice OsAAP5 is highly expressed in the leaves, but OsProT1, OsAUX1 and OsAUX2 expressed highly in the panicles (Zhao et al., 2012). Rice OsAAP6 functions as a positive regulator of grain protein content (Peng et al., 2014). 


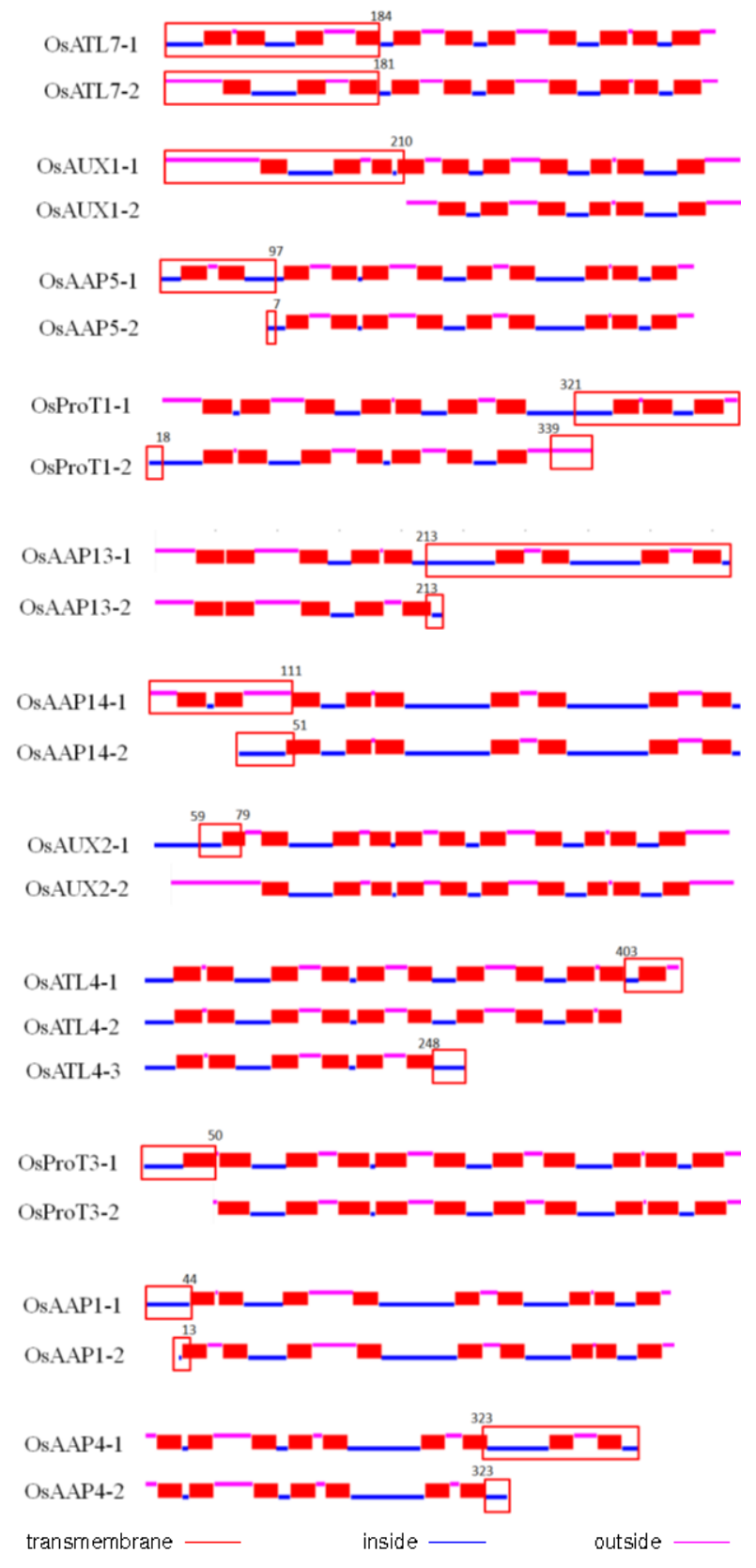

Fig. 3: Prediction of transmembrane domain in OsAAT splice variants proteins. The OsAAT splice variants sequence was acquired from http://rice.plantbiology.msu.edu/) and the analysis of sequence of protein use TMHMM Server v. 2.0 (http://www.cbs.dtu.dk/services/TMHMM/). The red box represents specific region of splice variant, and the number represents the position site of amino acids

Alternative splice variants of OsAAT genes showed differential expression during leaf development (Fig. 7). Expression of OsALT7-1/2, OsAUX1-1, OsAAP14-2 and OsProT3-1 increased from young to old leaves. However, the expression of OsAUX1-1, OsAAP5-1, OsProT1-1,

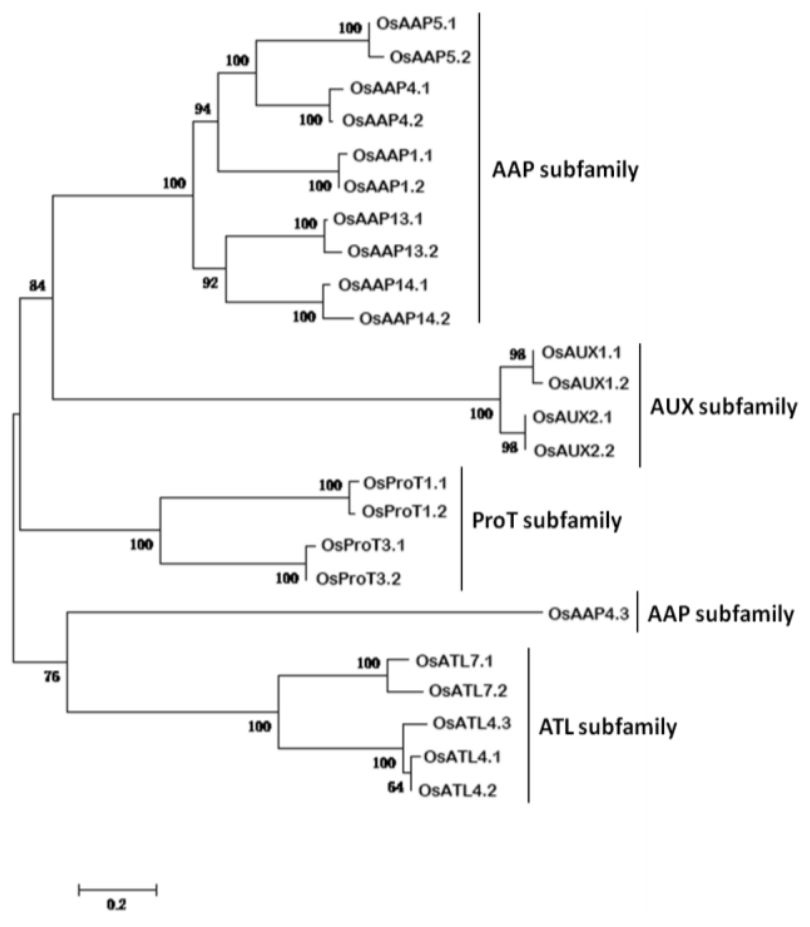

Fig. 4: Phylogenetic tree of OsAAT alternative splice variants based on amino acid sequence. The tree was drawn according to results generated by MEGA4.0 analysis using the neighbor-joining method with an amino acid and Poisson correction model. Bootstrap values calculated for 1,000 replicates are indicated at corresponding nodes. The 11 OsAAT alternative splice variants from rice were clustered into four sections. Locus IDs of OsAAT splice variants from rice are given in Table 1

OsAUX2-2 and OsAAP1-1 increased at the early stage and then decreased at the late stage. These changes in gene expression suggest that these genes play differential roles when flag leaves develop from young to old. In the developing panicles, alternative splice variants of $O S A A T$ genes also showed differential expression (Fig. 8). These findings suggested that different alternative splice variants of OsAAT genes play different roles during panicle development.

\section{Conclusion}

Eleven identified OsAAT genes showed differential expression via alternative splicing to adapt to environmental nutrition and developmental conditions. This study provides a new perspective on the wide divergence and regulation of splice variants in rice $A A T$ gene family. These data might provide an insight into further understanding the functions of $A A T$ members and their roles in rice growth and development. 
Expression Pattern of AAT Splice Variants in Rice / Int. J. Agric. Biol., Vol. 19, No. 5, 2017

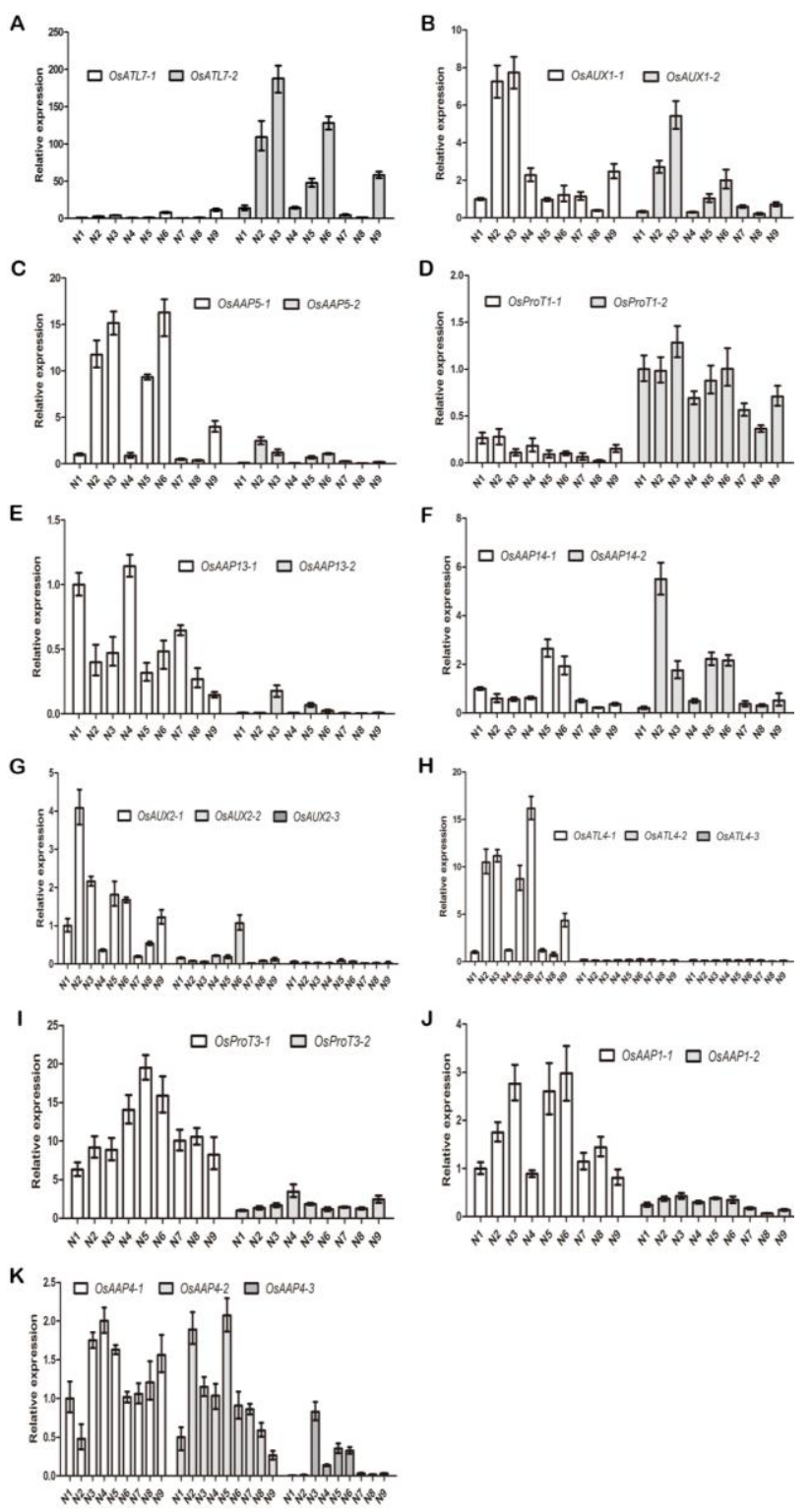

Fig. 5: Root expression patterns of $O S A A T$ alternative splice variants under different nitrogen conditions. For $\mathrm{N}$ treatments, seeds were soaked in water and germinated at $28^{\circ} \mathrm{C}$ for 2 days, and then cultured in the basic nutrient solution (Yoshida et al., 1976) with one of the following as the $\mathrm{N}$ source: $0.5 \mathrm{mM} \mathrm{KNO}_{3}(\mathrm{~N} 1), 2.0 \mathrm{mM} \mathrm{KNO}_{3}(\mathrm{~N} 2)$, $5.0 \mathrm{mM} \mathrm{KNO}_{3}(\mathrm{~N} 3), 0.25 \mathrm{mM}\left(\mathrm{NH}_{4}\right)_{2} \mathrm{SO}_{4}(\mathrm{~N} 4), 1 \mathrm{mM}$ $\left(\mathrm{NH}_{4}\right)_{2} \mathrm{SO}_{4}(\mathrm{~N} 5), 2.5 \mathrm{mM}\left(\mathrm{NH}_{4}\right)_{2} \mathrm{SO}_{4}(\mathrm{~N} 6), 0.25 \mathrm{mM}$ $\mathrm{NH}_{4} \mathrm{NO}_{3}(\mathrm{~N} 7), 1 \mathrm{mM} \mathrm{NH} \mathrm{NO}_{3}(\mathrm{~N} 8)$, or $2.5 \mathrm{mM} \mathrm{NH}_{4} \mathrm{NO}_{3}$ (N9). After one week of culture, roots of seedlings were harvested for total RNA isolation. Rice Actinl gene (AB047313) was used as an internal control. The ratio of relative expression set to 1 was the expression level of OsATL7-1, OsAUX1-1, OsAAP5-1, OsProT1-2, OsAAP131, OsAAP14-1, OsAUX2-1, OsATL4-1, OsProT3-2, OsAAP1-1, and OsAAP4-1 for each splice variant after treatment with $0.5 \mathrm{mM} \mathrm{KNO}_{3}(\mathrm{~N} 1)$

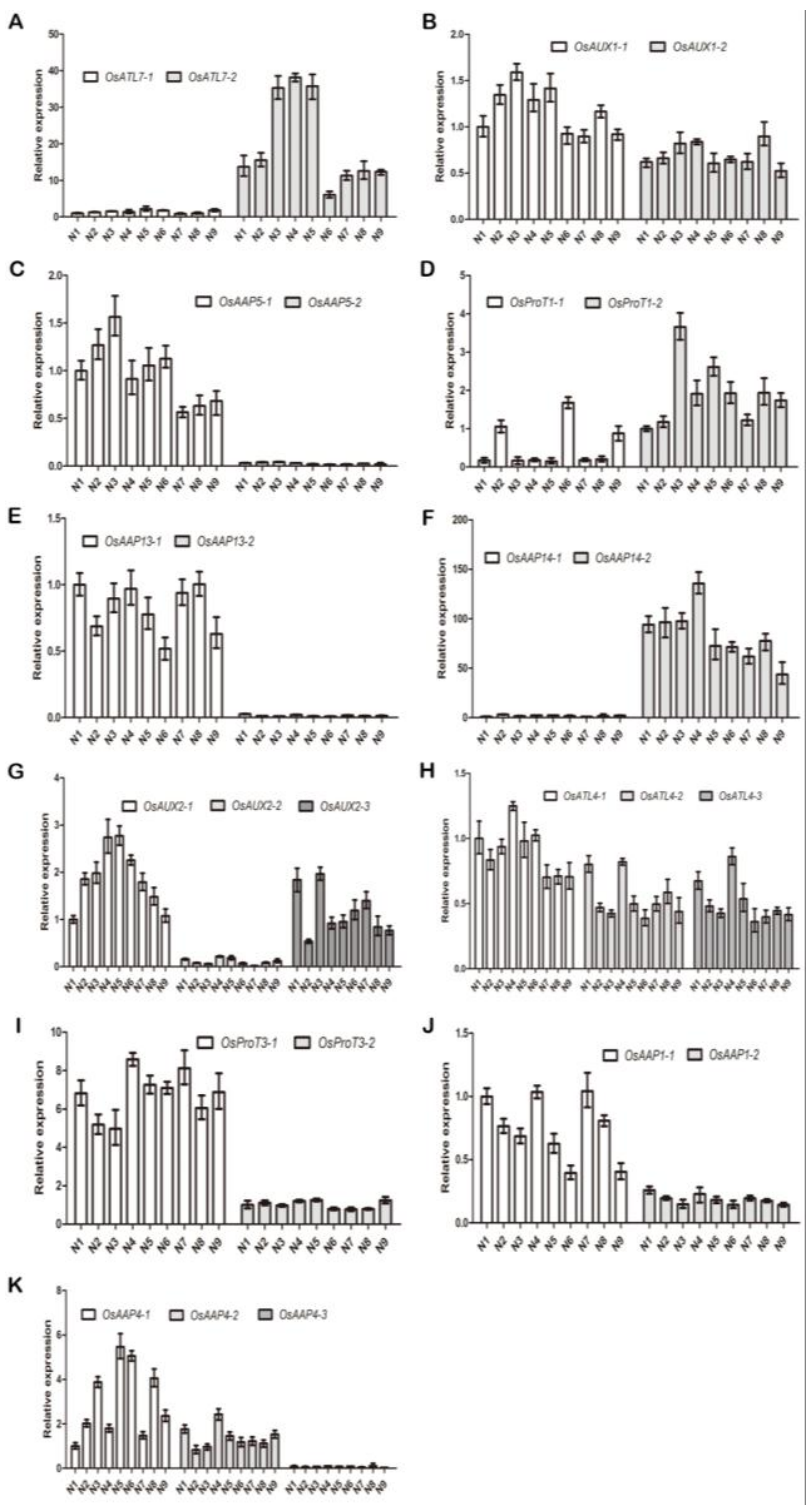

Fig. 6: Leaf expression patterns of $O S A A T$ alternative splice variants after different nitrogen treatments. Experimental conditions were the same as those shown Fig. 5. The ratio of relative expression set to 1 was the expression level of OsATL7-1, OsAUX1-1, OsAAP5-1, OsProT1-2, OsAAP13-1, OsAAP14-1, OsAUX2-1, OsATL4-1, OsProT3-2, OsAAP1-1, and $O S A A P 4-1$ for each splice variant after treatment with $0.5 \mathrm{mM} \mathrm{KNO}_{3}(\mathrm{~N} 1)$

\section{Acknowledgments}

This research was supported by grants from the National Natural Science Foundation (31301250) the open project of State Key Laboratory of Rice Biology (160203), Foundation of Guangdong Provincial Department of Science and Technology (2015B020231009), the fund of Guangdong 

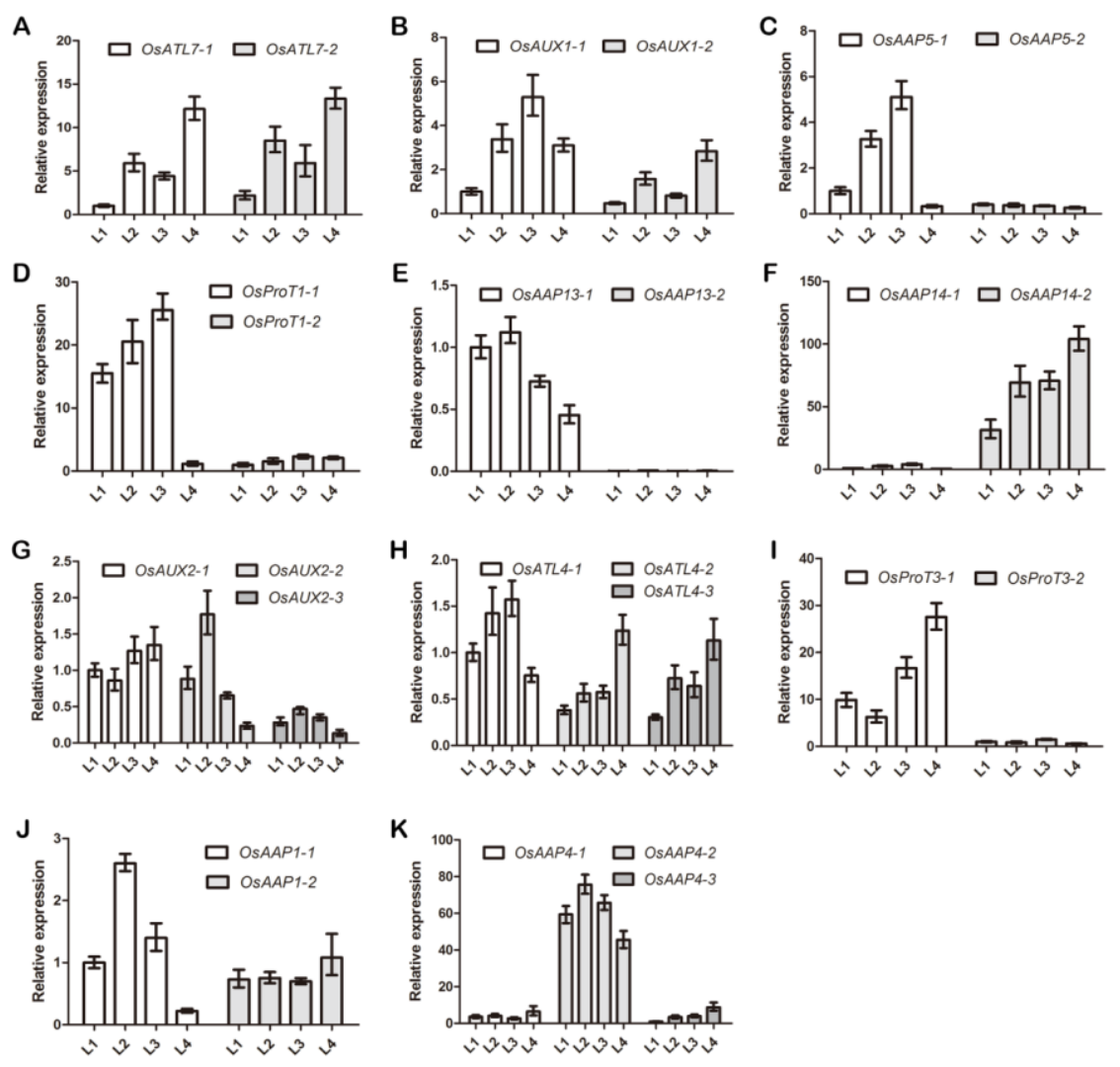

Fig. 7: Leaf expression patterns of $O s A A T$ alternative splice variants at different reproductive stages. Flag leaves at booting stage (L1), heading stage (L2), filling stage (L3), and mature stage (L4) of reproductive stage (90 d to 120 $\mathrm{d}$ after planting) in a paddy field were harvested for total RNA isolation. Rice Actinl gene (AB047313) was used as an internal control. The ratio of relative expression set to 1 was the expression level of OSATL7-1, OsAUX1-1, OsAAP5-1, OsProT1-2, OsAAP13-1, OsAAP14-1, OsAUX2-1, OsATL4-1, OsProT3-2, OsAAP1-1, and OsAAP4-1 for each splice variant at the booting stage (L1)

Provincial Department of Agriculture (Yuenongji 201742) and National Key Research and Development Program of China (2017YFD0100100).

\section{References}

Andrews, M., P.J. Lea, J.A. Raven and R.A. Azevedo, 2009. Nitrogen use efficiency. 3. Nitrogen fixation: genes and costs. Ann. Appl. Biol., 155: $1-13$

Bennett, M.J., A. Marchant, H.G. Green, S.T. May, S.P. Ward, P.A. Millner, A.R. Walker, B. Schulz and K.A. Feldmann, 1996. Arabidopsis AUX1 gene: a permease-like regulator of root gravitropism. Science, 273: 948-950

Campbell, M.A., B.J. Haas, J.P. Hamilton, S.M. Mount and C.R. Buell, 2006. Comprehensive analysis of alternative splicing in rice and comparative analyses with Arabidopsis. BMC Genom., 7: 1

Chen, L. and D.R. Bush, 1997. LHT1, a lysine-and histidine-specific amino acid transporter in Arabidopsis. Plant Physiol., 115: 1127-1134

Chen, L.S., A. Ortiz-Lopez, A. Jung and D.R. Bush, 2001. ANT1, an aromatic and neutral amino acid transporter in Arabidopsis. Plant Physiol., 125: 1813-1820

Cheng, L., H.Y. Yuan, R. Ren, S.Q. Zhao, Y.P. Han, Q.Y. Zhou, D.X. Ke, Y.X. Wang and L. Wang, 2016. Genome-wide identification, classification and expression analysis of amino acid transporter gene family in Glycine max. Front. Plant Sci., 7: 1-14
Coruzzi, G. and D.R. Bush, 2001. Nitrogen and carbon nutrient and metabolite signaling in plants. Plant Physiol., 125: 61-64

Couturier, J., E. De Faÿ, M. Fitz, D. Wipf, D. Blaudez and M. Chalot, 2010. PtAAP11, a high affinity amino acid transporter specifically expressed in differentiating xylem cells of poplar. J. Exp. Bot., 61: $1671-1682$

Fang, Z., K. Xia, X. Yang, M.S. Grotemeyer, S. Meier, D. Rentsch, X. Xu and M. Zhang, 2013. Altered expression of the PTR/NRT1 homologue OsPTR9 affects nitrogen utilization efficiency, growth and grain yield in rice. Plant Biotechnol. J., 11: 446-458

Fischer, W.N., B. André, D. Rentsch, S. Krolkiewicz, M. Tegeder, K. Breitkreuz and W.B. Frommer, 1998. Amino acid transport in plants. Trends Plant Sci., 3: 188-195

Fischer, W.N., M. Kwart, S. Hummel and W.B. Frommer, 1995. Substrate specificity and expression profile of amino acid transporters (AAPs) in Arabidopsis. J. Biol. Chem., 270: 16315-16320

Gillissen, B., L. Bürkle, B. André, C. Kühn, D. Rentsch, B. Brandl and W.B. Frommer, 2000. A new family of high-affinity transporters for adenine, cytosine and purine derivatives in Arabidopsis. Plant Cell, 12: $291-300$

Grallath, S., T. Weimar, A. Meyer, C. Gumy, M. Suter-Grotemeyer and J.M. Neuhaus, 2005. The AtProT family. Compatible solute transporters with similar substrate specificity but differential expression patterns. Plant Physiol., 137: 117-126

Graveley, B.R., 2001. Alternative splicing: increasing diversity in the proteomic world. Trends Genet., 17: 100-107 

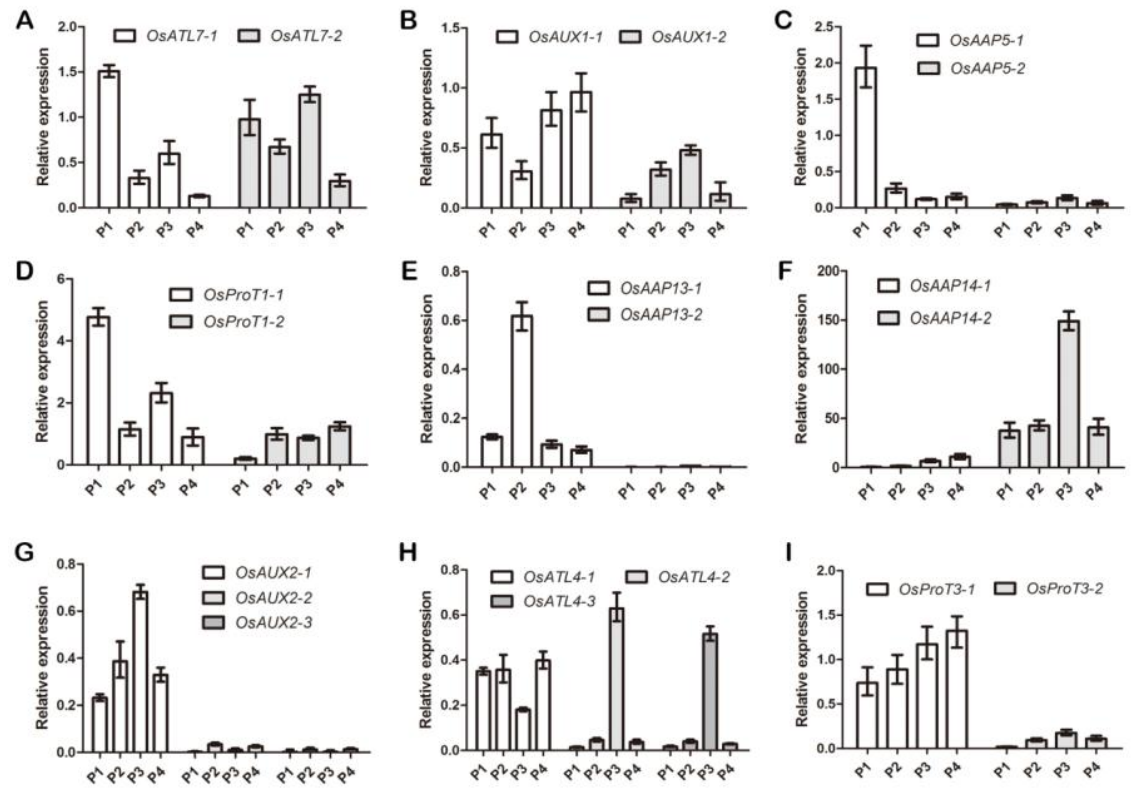

H
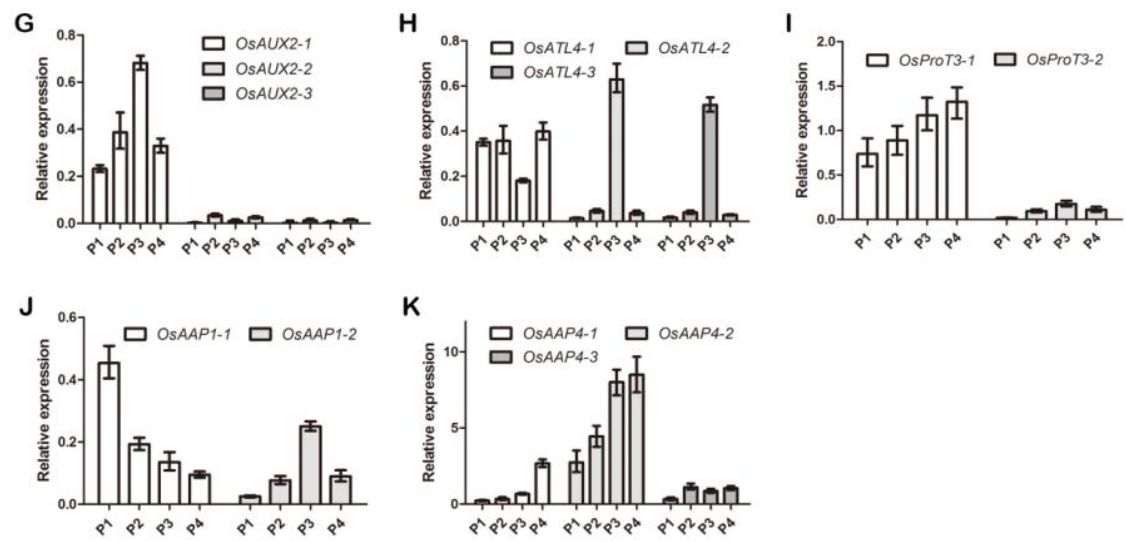

Fig. 8: Panicle expression patterns of $O S A A T$ alternative splice variants at different reproductive stages. Panicles at booting stage (P1), heading stage (P2), filling stage (P3), and mature stage (P4) of reproductive stage (90 d to $120 \mathrm{~d}$ after planting) in a paddy field were harvested for total RNA isolation. Rice Actinl gene (AB047313) was used as an internal control. The ratio of relative expression set to 1 was the expression level of OsATL7-1, OsAUX1-1, OsAAP5-1, OsProT1-2, OsAAP13-1, OsAAP14-1, OsAUX2-1, OsATL4-1, OsProT3-2, OsAAP1-1, and OsAAP4-1 for each splice variant at the booting stage (L1)

Hirner, A., F. Ladwig, H. Stransky, S. Okumoto, M. Keinath, A. Harms, W.B. Frommer and W. Kocha, 2006. Arabidopsis LHT1 is a highaffinity transporter for cellular amino acid uptake in both root epidermis and leaf mesophyll. Plant Cell, 18: 1931-1946

Hunt, E., S. Gattolin, H.J. Newbury, J.S. Bale, H.M. Tseng, D.A. Barrett and J. Pritchard, 2010. A mutation in amino acid permease AAP6 reduces the amino acid content of the Arabidopsis sieve elements but leaves aphid herbivores unaffected. J. Exp. Bot., 61: 55-64

Kriventseva, E.V., I. Koch, R. Apweiler, M. Vingron, P. Bork and M.S. Gelfand, 2003. Increase of functional diversity by alternative splicing. Trends Genet., 19: 124-128

Lee, Y.H., J. Foster, J. Chen, L.M. Voll, A.P. Weber and M. Tegeder, 2007. AAP1 transports uncharged amino acids into roots of Arabidopsis. Plant J., 50: 305-319

Lee, C., D. Chronis, C. Kenning, B. Peret, T. Hewezi, E.L. Davis, T.J. Baum, R. Hussey, M. Bennett and M.G. Mitchum, 2011. The novel cyst nematode effector protein $19 \mathrm{C} 07$ interacts with the Arabidopsis auxin influx transporter LAX3 to control feeding site development. Plant Physiol., 155: 866-880

Lu, Y., Z. Song, K. Lü, X. Lian and H. Cai, 2012. Molecular characterization, expression and functional analysis of the amino acid transporter gene family $(O s A A T s)$ in rice. Acta Physiol. Plant., 34 1943-1962

Ma, H.L., X.L. Cao, S.D. Shi, S.L. Li, J.P. Gao, Y.L. Ma, Q. Zhao and Q. Chen, 2016. Genome-wide survey and expression analysis of the amino acid transporter superfamily in potato (Solanum tuberosum L.). Plant Physiol. Biochem., 107: 164-177
Marchant, A., J. Kargul, S.T. May, P. Muller, A. Delbarre, C. PerrotRechenmann and M.J. Bennett, 1999. AUX1 regulates root gravitropism in Arabidopsis by facilitating auxin uptake within root apical tissues. EMBO J., 18: 2066-2073

Marschnert, H., E.A. Kirkby and C. Engels, 1997. Importance of cycling and recycling of mineral nutrients within plants for growth and development. Bot. Acta, 110: 265-273

Meyer, A., S. Eskandari, S. Grallath and D. Rentsch, 2006. At GAT1, a high affinity transporter for aminobutyric acid in Arabidopsis thaliana. $J$. Biol. Chem., 281: 7197-7204

Miller, A.J., X. Fan, Q. Shen and S.J. Smith, 2008. Amino acids and nitrate as signals for the regulation of nitrogen acquisition. J. Exp. Bot., 59: $111-119$

Näsholm, T., K. Kielland and U. Ganeteg, 2009. Uptake of organic nitrogen by plants. New Phytol., 182: 31-48

Okumoto, S., W. Koch, M. Tegeder, W.N. Fischer, A. Biehl, D. Leister, Y.D. Stierhof and W.B. Frommer, 2004. Root phloem-specific expression of the plasma membrane amino acid proton co-transporter AAP3. J. Exp. Bot., 55: 2155-2168

Ortiz-Lopez, A., H.C. Chang and D.R. Bush, 2000. Amino acid transporters in plants. Biochem. Biophys. Acta, 1465: 275-280

Paungfoo-Lonhienne, C., T.G. Lonhienne, D. Rentsch, N. Robinson, M. Christie, R.I. Webb, H.K. Gamage, B.J. Carroll, P.M. Schenk and S. Schmidt, 2008. Plants can use protein as a nitrogen source without assistance from other organisms. Proc. Natl. Acad. Sci. USA, 105: $4524-4529$ 
Peng, B., H.L. Kong, Y.B. Li, L.Q. Wang, M. Zhong, L. Sun, G.J. Gao, Q.L. Zhang, L.J. Luo, G.W.Wang, W.B. Xie, J.X. Chen, W. Yao, Y. Peng, L. Lei, X.M. Lian, J.H. Xiao, C.G. Xu, X.H. Li and Y.Q. He, 2014. OsAAP6 functions as an important regulator of grain protein content and nutritional quality in rice. Nat. Commun., 5: Article 4847

Perchlik, M., J. Foster and M. Tegeder, 2014. Different and overlapping functions of Arabidopsis LHT6 and AAP1 transporters in root amino acid uptake. J. Exp. Bot., 65: 5193-5204

Reed, J.W., 2001. Roles and activities of Aux/IAA proteins in Arabidopsis. Trends Plant Sci., 6: 420-425

Santiago, J.P. and M. Tegeder, 2016. Connecting source with sink: the role of Arabidopsis AAP8 in phloem loading of amino acids. Plant Physiol., 171: 508-521

Sanders, A., R. Collier, A. Trethewy, G. Gould, R. Sieker and M. Tegeder, 2009. AAP1 regulates import of amino acids into developing Arabidopsis embryos. Plant J., 59: 540-552

Schmidt, R., H. Stransky and W. Koch, 2007. The amino acid permease AAP8 is important for early seed development in Arabidopsis thaliana. Planta, 226, 805-813

Schwacke, R., S. Grallath, K.E. Breitkreuz, E. Stransky, H. Stransky, W.B. Frommer and D. Rentsch, 1999. LeProT1, a transporter for proline, glycine betaine and $\gamma$-amino butyric acid in tomato pollen. Plant Cell, 11: 377-391

Schulze, W., W.B. Frommer and J.M. Ward, 1999. Transporters for ammonium, amino acids and peptides are expressed in pitchers of the carnivorous plant Nepenthes. Plant J., 17: 637-646

Sonoda, Y., A. Ikeda, S. Saiki, T. Yamaya and J. Yamaguchi, 2003. Feedback regulation of the ammonium transporter gene family AMTl by glutamine in rice. Plant Cell Physiol., 44: 1396-1402
Svennerstam, H., U. Ganeteg and T. Näsholm, 2008. Root uptake of cationic amino acids by Arabidopsis depends on functional expression of amino acid permease 5. New Phytol., 180: 620-630

Taylor, M.R., A. Reinders and J.M. Ward, 2015. Transport function of rice amino acid permeases (AAPs). Plant Cell Physiol., 56: 1355-1363

Tegeder, M., 2012. Transporters for amino acids in plant cells: some functions and many unknowns. Curr. Opin. Plant Biol., 15: 315-321

Tegeder, M. and J.M. Ward, 2012. Molecular evolution of plant AAP and LHT amino acid transporters. Front. Plant Sci., 3: 21

Tegeder, M., 2014. Transporters involved in source to sink partitioning of amino acids and ureides: opportunities for crop improvement. J. Exp. Bot., 65: 1865-1878

Wang, B.B. and V. Brendel, 2006. Genomewide comparative analysis of alternative splicing in plants. Proc. Natl. Acad. Sci. USA, 103: 7175-7180

Wu, M., S.N. Wu, Z. Chen, Q. Dong, H.W. Yan and Y. Xiang, 2015. Genome-wide survey and expression analysis of the amino acid transporter gene family in poplar Tree. Genet. Genom., 11: 83

Yoshida, S., D.A. Forno, J.H. Cock and K.A. Gomez, 1976. Laboratory Manual for Physiological Studies of Rice. International Rice Research Institute, Los Banos, Philippines

Zhang, L.Z., Q.M. Tan, R. Lee, A. Trethewy, Y.H. Lee and M. Tegeder, 2010. Altered xylem-phloem transfer of amino acids affects metabolism and leads to increased seed yield and oil content in Arabidopsis. Plant Cell, 22: 3603-3620

Zhao, H., H. Ma, L. Yu, X. Wang and J. Zhao, 2012. Genome-wide survey and expression analysis of amino acid transporter gene family in rice (Oryza sativa L.). PloS One, 7: e49210

(Received 09 May 2017; Accepted 31 May 2017) 